\title{
Agronomic characters and disease management in second season corn using calcium, copper, manganese and zinc products
}

\section{Caracteres agronômicos e manejo de doenças em milho de segunda safra por produtos à base de cálcio, cobre, manganês e zinco}

\author{
Eloisa Lorenzetti ${ }^{1 *} \mathbb{D}$; Juliano Tartaro ${ }^{2} \mathbb{D}$, José Renato Stangarlin ${ }^{3} \mathbb{D}$, Odair José Kuhn ${ }^{3}$
}

\author{
'Universidade Federal do Paraná/UFPR, Palotina, PR, Brasil \\ ${ }^{2}$ Cooperativa Agroindustrial Copagril, Marechal Cândido Rondon, PR, Brasil \\ ${ }^{3}$ Universidade Estadual do Oeste do Paraná/UNIOESTE, Marechal Cândido Rondon, PR, Brasil \\ *Corresponding author: eloisa-lorenzetti@hotmail.com \\ Received in October 25, 2019 and approved in April 1, 2020
}

\begin{abstract}
Corn is a cereal whose productivity can be reduced by various diseases which has recommended treatments for control. The objective of this study was to analyze copper, zinc, calcium and manganese products for the management of Pantoea ananatis, Puccinia polysora and Cercospora zeae maydis in second season corn, and interference in agronomic characteristics. Commercial products made of amino acid chelated with 15\% calcium, 5\% copper, $15 \%$ manganese and $10 \%$ zinc, at the doses of $0.5 \mathrm{~kg} \mathrm{ha}^{-1}, 0.3 \mathrm{~L} \mathrm{ha}^{-1}, 0.4 \mathrm{~kg} \mathrm{ha}^{-1}$ and $1 \mathrm{~L} \mathrm{ha-1}$, respectively, a treatment with fungicide ( $20 \%$ azoxystrobin and $8 \%$ cyproconazole at $0.3 \mathrm{~L} \mathrm{ha}^{-1}+25 \%$ propiconazole at $0.4 \mathrm{~L} \mathrm{ha-1}$ ), and a treatment with water were assayed. The experiments were carried out under field conditions for two consecutive years and in two simple hybrids, in soil supplemented with nutrients based on the chemical analysis. The plant height, stem diameter, number of rows per spike, number of grains per row of spike, productivity and mass of one thousand grains were evaluated. Disease severity was assessed with diagrammatic scales and calculated the area under the disease progress curves. In both years, there was no significant effect of chelates for agronomic traits and diseases severity. It is concluded that chelate-based calcium, copper, manganese and zinc products have no influence on agronomic characteristics and severity of the diseases evaluated in second season corn for those edaphoclimatic conditions.
\end{abstract}

Index terms: Alternative control; nutrition; Zea mays L.

\section{RESUMO}

O milho é um cereal cuja produtividade pode ser reduzida por diversas doenças foliares, o que tem preconizado tratamentos para controle. O objetivo deste estudo foi analisar se produtos à base de cobre, zinco, cálcio e manganês são eficientes para manejo de Pantoea ananatis, Puccinia polysora e Cercospora zeae maydis em milho de segunda safra, e se interferem nos caracteres agronômicos. Foram testados produtos comerciais quelatos de aminoácidos com os elementos cálcio 15\%, cobre 5\%, manganês 15\% e zinco 10\%, na dose de $0,5 \mathrm{~kg} \mathrm{ha}^{-1}, 0,3 \mathrm{~L} \mathrm{ha}^{-1}, 0,4 \mathrm{~kg} \mathrm{ha}^{-1}$ e $1 \mathrm{~L} \mathrm{ha}^{-1}$, respectivamente, um tratamento com fungicida (azoxistrobina 20\% e ciproconazol $8 \%$ na dose de $0,3 \mathrm{~L} \mathrm{ha}^{-1}+$ propiconazol $25 \%$ na dose de $0,4 \mathrm{~L} \mathrm{ha}^{-1}$ ), e um tratamento com água. Os ensaios foram realizados em campo por dois anos consecutivos e em dois híbridos simples, em solo cuja fertilidade foi corrigida baseada na análise química do mesmo. Foram avaliados os caracteres agronômicos altura de plantas, diâmetro de colmo, número de fileiras por espiga, número de grãos por fileira da espiga, produtividade e massa de mil grãos. A severidade das doenças foi avaliada com escala diagramática ou através de estimativas de severidade, dependendo do patossistema, e os dados foram utilizados para calcular a área abaixo da curva de progresso da doença. Em nenhum dos anos estudados foi registrado efeito significativo dos quelatos para os caracteres agronômicos e para a severidade das doenças que ocorreram nas condições em que o estudo foi conduzido. Novos trabalhos em solos e ambientes diferentes e utilizando híbridos distintos poderão apresentar resultados satisfatórios, assim como em área onde se verifica deficiência destes nutrientes. Concluise através deste estudo que produtos à base de cálcio cobre, manganês e zinco não tem influência sobre caracteres agronômicos e severidade das doenças avaliadas em milho de segunda safra para as condições edafoclimáticas de condução dos trabalhos.

Termos para indexação: Controle alternative; nutrição; Zea mays L.

\section{INTRODUCTION}

An adequate fertilization corroborates for corn (Zea mays L.) development and for high levels of productivity, however, this and other agronomic traits may be affected by several factors, such as the occurrence of diseases, that has worsened by the increase in maize cultivation in the second season or "safrinha" (Carvalho; Pereira; Camargo, 2016). 
Among the diseases occurring in corn cultivated in second season, the gray leaf spot (Cercospora zeae-maydis (T. Daniels)), the white spot (Phaeosphaeria maydis and Pantoea ananatis complex) and the Southern rust (Puccinia polysora Underw) are responsible for damaging the production (Carvalho; Pereira; Camargo, 2016).

The use of fungicides (Wordell Filho; Casa, 2010) and additional plant nutrition (Duarte, Juliatti; Freitas, 2009) can reduce the damage caused by those diseases. The balance of nutrients in plants can cause changes in their chemical, morphological and histological parameters (Fahad; bano, 2012), reducing the development of diseases due the fact of plants become less predisposed to infection by pathogens (Bedendo; Amorim; Mattos-Jr, 2018). However, if the plants are growth in a soil with adequate amount of nutrients, are the additional leaf fertilization necessary for management of diseases?

Thus, this work aimed to verify whether chelatebased products among amino acids and the elements calcium, copper, manganese and zinc has an influence on the management of corn leaf diseases and in the agronomic traits of two simple hybrids under second season condition.

\section{MATERIAL AND METHODS}

The assays were conducted in the second season (autumn/winter) of two consecutive years (2017 and 2018), in Toledo, Paraná State, Brazil, at geographic coordinates $24^{\circ} 32^{\prime} 30^{\prime \prime} \mathrm{S}$ and $53^{\circ} 54^{\prime} 32^{\prime \prime} \mathrm{W}$, and altitude of $386 \mathrm{~m}$. The soil is clayey textured, classified as Eutroferric Red Latosol, from basalt (Santos et al., 2013).

Prior to the implantation of the experiment, in the 2017 crop, the soil was collected for chemical and physical analysis, and after harvest of 2018 was collected again for chemical analysis in order to verify the chemical content (Table 1). The precipitation and temperature data for the two second harvests (2017 and 2018) were collected, but not presented.

Table 1: Chemical and granulometric characterization of the Eutroferric Red Latosol before the implantation of the experiments.

\begin{tabular}{|c|c|c|c|c|c|c|c|c|}
\hline \multicolumn{9}{|c|}{ Second crop of 2017} \\
\hline Depth & $\mathrm{H}+\mathrm{Al}$ & K & $\mathrm{Al}$ & $\mathrm{Ca}$ & $\mathrm{Mg}$ & SB & CTC & $\mathrm{V}$ \\
\hline & \multicolumn{7}{|c|}{$\mathrm{cmol}_{\mathrm{c}} \mathrm{dm}^{-3} \longrightarrow$} & $\%$ \\
\hline $0-20 \mathrm{~cm}$ & 6.69 & 0.28 & 0.03 & 8.06 & 2.14 & 10.48 & 17.17 & 61.04 \\
\hline \multirow[t]{2}{*}{ Depth } & C & $P$ & & $\mathrm{pH}$ & $\mathrm{Fe}$ & $\mathrm{Mn}$ & $\mathrm{Cu}$ & $\mathrm{Zn}$ \\
\hline & $g d^{-3}$ & \multicolumn{2}{|c|}{$\mathrm{mg} \mathrm{dm}^{-3}$} & $\mathrm{CaCl}_{2}$ & & \multicolumn{2}{|c|}{$m g d m^{-3}$} & \\
\hline $0-20 \mathrm{~cm}$ & 15.63 & & 50 & 4.90 & 21.20 & 73.16 & 19.20 & 5.47 \\
\hline \multicolumn{9}{|c|}{ Granulometry } \\
\hline \multirow[t]{2}{*}{ Depth } & \multicolumn{3}{|c|}{ Clay } & \multicolumn{2}{|c|}{ Silt } & & \multicolumn{2}{|c|}{ Sand } \\
\hline & \multicolumn{8}{|c|}{$\mathrm{g} \mathrm{kg}^{-1}$} \\
\hline $0-50 \mathrm{~cm}$ & \multicolumn{3}{|c|}{662.5} & \multicolumn{2}{|c|}{162.5} & & \multicolumn{2}{|c|}{175.0} \\
\hline \multicolumn{9}{|c|}{ Second crop of 2018} \\
\hline \multirow[t]{2}{*}{ Depth } & $\mathrm{H}+\mathrm{Al}$ & K & Al & & & SB & CTC & V \\
\hline & \multicolumn{7}{|c|}{$\mathrm{cmol}_{c} \mathrm{dm}^{-3}$} & $\%$ \\
\hline $0-20 \mathrm{~cm}$ & 5.76 & 0.42 & 0.00 & & & 9.70 & 15.46 & 62.74 \\
\hline \multirow[t]{2}{*}{ Depth } & C & $\mathrm{P}$ & & & & $\mathrm{Mn}$ & $\mathrm{Cu}$ & $\mathrm{Zn}$ \\
\hline & $g \mathrm{dm}^{-3}$ & $\mathrm{mg} \mathrm{c}$ & & & & $-m g d m$ & - & \\
\hline $0-20 \mathrm{~cm}$ & 18.25 & 38. & & & & 75.50 & 16.80 & 7.30 \\
\hline \multicolumn{9}{|c|}{ Granulometry } \\
\hline \multirow{2}{*}{\multicolumn{2}{|c|}{ Depth }} & $\mathrm{Cla}$ & & \multicolumn{2}{|c|}{ Silt } & & \multicolumn{2}{|c|}{ Sand } \\
\hline & & \multicolumn{5}{|c|}{$\mathrm{g} \mathrm{kg}^{-1}$} & & \\
\hline $0-50$ & & 662 & & & & & \multicolumn{2}{|c|}{175.0} \\
\hline
\end{tabular}

Extractor Melich: K - P - Fe - Mn - Cu and Zn; extractor $\mathrm{KCl}$ : Ca - Mg - Al; extractor $\mathrm{HCl}$ 0,05 N: B; extractor calcium phosphate: S; extractor sodium dichromate: carbon. 
The experimental design was a randomized block in a factorial scheme $2 \times 6$, two hybrids and six treatments (calcium, copper, manganese, zinc, fungicide and water). The experimental area was divided into four blocks, with a total of 48 plots with a useful area of $10.8 \mathrm{~m}^{2}$ each $(4.0$ $\mathrm{m}$ length $\mathrm{x} 0.90 \mathrm{~m}$ between linesx three lines).

Two simple hybrids were used, 30A37PW and FÓRMULA VIPTERA, with recommendation for cultivation in the west of Paraná State. The hybrids were chosen for differences in tolerance, resistance and susceptibility to frequent leaf diseases in the region, and also by similarity in the cycles so that there was a coincidence of the phenological stage at the time of application of the products and assessments.

The sowings were performed on February $23^{\text {th }}$ 2017 and February $24^{\text {th }} 2018$, under no tillage system, on corn straw. Fertilization at the time of sowing was carried out taking into account the results of the chemical analysis of the soil, using $310 \mathrm{~kg} \mathrm{ha}^{-1}$ of the 11-19-14 (NPK), containing $34 \mathrm{~kg}$ nitrogen (N), $59 \mathrm{~kg}$ phosphorus $\left(\mathrm{P}_{2} \mathrm{O}_{5}\right), 43 \mathrm{~kg}$ Potassium $\left(\mathrm{K}_{2} \mathrm{O}\right), 0.375 \mathrm{~kg}$ boron, $0.375 \mathrm{~kg}$ copper, $0.750 \mathrm{~kg}$ manganese and $0.750 \mathrm{~kg}$ zinc (Pauletti; Motta, 2019). For covering fertilization, urea was used in two applications, the first in the phenological stage $\mathrm{V}_{3}$ $\left(70 \mathrm{~kg} \mathrm{ha}^{-1} \mathrm{~N}\right)$ and the second in $\mathrm{V}_{6}\left(70 \mathrm{~kg} \mathrm{ha}^{-1} \mathrm{~N}\right)$, aiming at higher productivity than $12.000 \mathrm{~kg} \mathrm{ha}^{-1}$.

Manual weede was performed according to the need, and for the control of insect pests, two applications were performed, the first of thiamethoxam + lambdacyhalothrin $\left(0.25 \mathrm{~L} \mathrm{ha}^{-1}\right)$ when the plants were in the phenological stage $\mathrm{V}_{1}$, and the second of imadacloprido + beta-cyflutrine $\left(1 \mathrm{~L} \mathrm{ha}^{-1}\right)$ in $\mathrm{V}_{3}$.

As treatments were used: chelated products between amino acids and the $15 \%$ calcium, $5 \%$ copper, $15 \%$ manganese and $10 \%$ zinc, elements, at the doses of $0.5 \mathrm{~kg} \mathrm{ha}^{-1}, 0.3 \mathrm{~L} \mathrm{ha}^{-1}, 0.4 \mathrm{~kg} \mathrm{ha}^{-1}$ and $1 \mathrm{~L} \mathrm{ha}^{-1}$, respectively; a fungicide $(20 \%$ azoxystrobin and $8 \%$ cyproconazole at $0.3 \mathrm{~L} \mathrm{ha}^{-1}+25 \%$ propiconazole at $0.4 \mathrm{~L} \mathrm{ha}^{-1}$ ); and water.

The treatments were administered 30 and 50 days after emergence, when more than $50 \%$ of the plants were in the phenological stages $V_{8}$ and $V_{T}$, respectively. In both stages the application was performed using model costal sprayer Jacto PJH 20 L with empty conical jet spray nozzle, and using a volume of $100 \mathrm{~L} \mathrm{ha}^{-1}$.

The agronomic traits evaluated were: plant height (from the soil to the curvature of the flag leaf, one week after flowering); stem diameter (in the middle of the first expanded internode, when the feminine floweringstyle-stigma was visible); number of rows and number of grains per row (in 20 spikes); mass of one thousand grains (corrected to $14 \%$ humidity, according to Brazilian Rule of Seed Analysis (Brasil, 2009); and productivity $\left(\mathrm{kg} \mathrm{ha}^{-1}\right)$.

Disease severity was evaluated from the natural infection of the pathogens, with no inoculation. The percentage of leaf area with symptoms was measured by diagrammatic scale for each disease, when available in literature. The evaluation was in the leaf below and opposite to the spike, in 10 plants every seven days. The data of severity were used to calculate the area under the disease progress curve (Shaner; Finney, 1977).

In 2017assay there was the incidence of white spot, gray leaf spot and Southern rust, therefore, the diagrammatic scales proposed by Sachs et al. (2011) for white spot, and by Agroceres (1994) for Southern rust, were used. To gray leaf spot, as no scale was found in the literature, the severity was estimated. For 2018 assay there was the incidence of the same diseases of 2017, except Southern rust.

For statistical analysis, we used the free software Genes (Cruz, 2016). The data were submitted to analysis of variance and the averages compared by the Tukey test.

\section{RESULTS AND DISCUSSION}

The analysis of variance showed that for both 2017 and 2018 assays there was significance of the treatments for the productivity. To the mass of a thousand grains, in 2018 assay a significant effect of the interaction among hybrids and treatments was observed, showing that the same treatment may behave differently depending on the hybrid, and it is necessary to consider these two factors.

For all variables evaluated, in both years, there was a significant effect for the hybrids, but these data were not shown and discussed, because the aim of this study was to verify the behavior of the treatments independently of the hybrid, since they already have differences due their distinct genetic characteristics.

The productivity in the assay of 2017 was different only between fungicide and water, but all other treatments did not differ statistically either from the fungicide neither from the water (Table 2).

For the variable mass of a thousand grains in the assay of 2018, for all treatments the largest mass was recorded for the hybrid 30A37PW. For this hybrid, all treatments were statistically equal, whereas for hybrid FÓRMULA VIPTERA, the largest mass of a thousand grains occurred with the use of the fungicide, and all the other treatments were equal to water (Table 3 ). This result shows dependence between treatments and hybrids, i.e., a certain treatment may have distinct behaviour depending on the hybrid in which it is applied. 
Table 2: Productivity (Kg ha ${ }^{-1}$ ) of corn, hybrids 30A37PW and FÓRMULA VIPTERA, treated with chelates-based products of calcium, copper, manganese and zinc. Novo Sarandi, Toledo - PR, second season, 2017.

\begin{tabular}{cc}
\hline Treatments & Productivity $\left(\mathrm{Kg} \mathrm{ha}^{-1}\right)$ \\
\hline Calcium & $11,215.58 \mathrm{ab}$ \\
Copper & $11,188.58 \mathrm{ab}$ \\
Manganese & $11,439.67 \mathrm{ab}$ \\
Zinc & $10,881.07 \mathrm{ab}$ \\
Fungicide & $11,812.73 \mathrm{a}$ \\
Water & $10,572.67 \mathrm{~b}$ \\
MSD & $1,108.69$ \\
\hline
\end{tabular}

*Means followed by the same lowercase letter in the column do not differ statistically by the Tukey test ( $p<0.05$ ). MSD: minimum significant difference.

Table 3: Mass of a thousand grains (MTG) (g) of corn, hybrids 30A37PW and FÓRMULA VIPTERA, treated with chelates-based products of calcium, copper, manganese and zinc. Novo Sarandi, Toledo - PR, second season, 2018.

\begin{tabular}{ccc}
\hline Treatments & 30A37PW & FÓRMULA VIPTERA \\
\hline Calcium & $386.06 \mathrm{Aa}$ & $326.33 \mathrm{Bb}$ \\
Copper & $390.26 \mathrm{Aa}$ & $328.94 \mathrm{Bb}$ \\
Manganese & $384.83 \mathrm{Aa}$ & $328.50 \mathrm{Bb}$ \\
Zinc & $382.74 \mathrm{Aa}$ & $334.29 \mathrm{Bb}$ \\
Fungicide & $388.73 \mathrm{Aa}$ & $359.08 \mathrm{Ba}$ \\
Water & $376.40 \mathrm{Aa}$ & $333.51 \mathrm{Bb}$ \\
MSD & 15.10 & 22.42 \\
\hline
\end{tabular}

*Means followed by the same lowercase letter in the column do not differ statistically by the Tukey test ( $p<0.05$ ). MSD: minimum significant difference.

Thus, it was observed that there was no increment of the mass of one thousand grains with the use of calcium, copper, manganese or zinc, since they did not differ from water in any of the hybrids studied. Only the fungicide, for the hybrid FÓRMULA VIPTERA showed an increment of the mass of one thousand grains, differing from the other. This increase was due to the action of fungicide on the fungi causing those diseases, and then reducing the degradation and loss of grain quality (Mendes et al., 2011). Possibly, from the fact that the hybrid FÓRMULA VIPTERA be more susceptible to the diseases that occurred during the conduction of the experiment, the effect of the fungicide was more perceptible, since the hybrid 30A37PW presented, for all diseases studied, lower susceptibility and with lower severity values, which may have contributed to the results found in this agronomic trait.

According to Cunha et al. (2010) the mass of grains is directly influenced by the use of fungicides, because they are able to preserve the leaf area, responsible for the photosynthesis for longer, and may extend to the filling of grains, which according Brito et al. (2011) is part of the critical period of corn growth, because any stress, for example, the decrease in the photosynthetic area between pre-flowering and the beginning of grain filling, leads to significant losses in the production.

The productivity was different between fungicide and water in assay of 2018, and all other treatments were equal to both (Table 4). Manfroi et al. (2016) found higher corn production by performing two applications of the same fungicide used in this study and in the same phenological stages of spraying. Rosa et al. (2017) also found increased corn yield using fungicide (azoxystrobin + cyproconazole).

Table 4: Productivity $\left(\mathrm{Kg} \mathrm{ha}^{-1}\right)$ of corn, hybrids 30A37PW and FÓRMULA VIPTERA, treated with chelates-based products of calcium, copper, manganese and zinc. Novo Sarandi, Toledo - Paraná, second season, 2018.

\begin{tabular}{cc}
\hline Treatments & Productivity $\left(\mathrm{Kg} \mathrm{ha}^{-1}\right)$ \\
\hline Calcium & $12,665.78 \mathrm{ab}$ \\
Copper & $12,761.11 \mathrm{ab}$ \\
Manganese & $12,759.43 \mathrm{ab}$ \\
Zinc & $12,764.47 \mathrm{ab}$ \\
Fungicide & $13,581.49 \mathrm{a}$ \\
Water & $12,551.08 \mathrm{~b}$ \\
MSD & 948.01 \\
\hline
\end{tabular}

*Means followed by the same lowercase letter in the column do not differ statistically by the Tukey test ( $p<0.05$ ). MSD: minimum significant difference.

It was observed that for productivity, in the two years of conduction of the experiments, chelates with calcium, copper, manganese and zinc did not differ from water and fungicide. The probable mode of operation of these chelated products would be to assist in the induction of resistance or have direct fungitoxic action on some pathogens causing diseases, which limit productivity and agronomic traits related to the same. To verify these influences, new studies should be conducted to analyse enzymes or structures involved in the induction process 
of resistance in corn plants, or also, studies verifying the direct fungitoxic action of these chelates based on calcium, copper, manganese and zinc on the pathogens, as spore germination inhibition, for example.

The largest mass of a thousand grains and the highest productivity observed in the assay of 2018 with the use of hybrid 30A37PW, may have occurred because this hybrid has lower disease severity, due to its lower susceptibility comparing to the hybrid FÓRMULA VIPTERA.

Zambolim and Ventura (2012) state that high yields are dependent on fertility with minerals, but also the correct management to control both pests and diseases. According to these authors, the most important factors that influence the crop yields are essential nutrients supplementation and diseases management.

As the soil was corrected before the implantation of the experiments and due to the fact that adequate base fertilization was used, including micronutrients, it may be that foliar nutrient application would not be necessary, thus, expressive increments were not observed in the agronomic traits studied.

The incidence of white spot and gray leaf spot for both 2017 and 2018 assays was similar, whereas the Southern rust occurred only in the assay of 2017. Generally, due to changes in the environment with different temperatures and rainfall, different diseases are recorded influenced by the presence of the pathogen or on their arrival in the area, favoring the infectious process (Zambolim; Ventura, 2012).

In the assay of 2017 , there was significant interaction for white spot and gray leaf spot, while for Southern rust, only the hybrid effect was significant, being this data not shown and discussed.

For the assay of 2018, treatments and hybrids were significant for white spot, while for gray leaf spot, the interaction between hybrids and treatments was significant, demonstrating dependence between these factors.

The severity of white spot in the assay of 2017 was higher in the hybrid FÓRMULA VIPTERA (Table 5). No difference was observed among calcium, copper, manganese, zinc, fungicide and water in the hybrid 30A37PW, unlike what happened in the hybrid FÓRMULA VIPTERA, where the fungicide differed from the others presenting lower severity.

The difference in severity levels recorded for the evaluated hybrids was probably since the $30 \mathrm{~A} 37 \mathrm{PW}$ be moderately resistant to the white spot, while the FÓRMULA VIPTERA is moderately susceptible (Cruz et al., 2015).
Table 5: Area under white spot progress curve in corn treated with chelates-based products of calcium, copper, manganese and zinc, using the hybrids 30A37 and FÓRMULA VIPTERA em Novo Sarandi, Toledo - PR, second season, 2017.

\begin{tabular}{clc}
\hline Treatments & 30A37PW & FÓRMULA VIPTERA \\
\hline Calcium & $33.78 \mathrm{Ba}$ & $370.65 \mathrm{Aa}$ \\
Copper & $31.98 \mathrm{Ba}$ & $360.51 \mathrm{Aa}$ \\
Manganese & $32.32 \mathrm{Ba}$ & $364.76 \mathrm{Aa}$ \\
Zinc & $34.71 \mathrm{Ba}$ & $374.63 \mathrm{Aa}$ \\
Fungicide & $15.44 \mathrm{Ba}$ & $366.72 \mathrm{Ab}$ \\
Water & $41.59 \mathrm{Ba}$ & $389.21 \mathrm{Aa}$ \\
MSD & 19.58 & 29.08 \\
\hline
\end{tabular}

* Means followed by the same lowercase letter in the column do not differ statistically by the Tukey test ( $p<0.05)$. MSD: minimum significant difference.

Concerning gray leaf spot severity in the assay of 2017 (Table 6), there was difference between the hybrids. For the hybrid 30A37PW the treatments showed no difference, whereas for the hybrid FÓRMULA VIPTERA, the fungicide showed lower disease severity, differing from the treatments with calcium, copper, manganese, zinc and water. The hybrid 30A37PW has moderate resistance against gray leaf spot $(C$. zea-maydis) (Pereira Filho; Borghi, 2016; Cruz et al., 2015), which may justify the lowest severity compared to FÓRMULA VIPTERA, which is susceptible (Cruz et al., 2015).

Table 6: Area under gray leaf spot progress curve in corn, hybrids 30A37PW and FÓRMULA VIPTERA, treated with chelates-based products of calcium, copper, manganese and zinc. Novo Sarandi, Toledo PR, second season, 2017.

\begin{tabular}{clc}
\hline Treatments & 30A37PW & FÓRMULA VIPTERA \\
\hline Calcium & $46.86 \mathrm{Ba}$ & $215.77 \mathrm{Aa}$ \\
Copper & $42.27 \mathrm{Ba}$ & $215.92 \mathrm{Aa}$ \\
Manganese & $45.09 \mathrm{Ba}$ & $218.75 \mathrm{Aa}$ \\
Zinc & $47.92 \mathrm{Ba}$ & $227.50 \mathrm{Aa}$ \\
Fungicide & $20.56 \mathrm{Ba}$ & $126.26 \mathrm{Ab}$ \\
Water & $50.06 \mathrm{Ba}$ & $245.47 \mathrm{Aa}$ \\
MSD & 20.13 & 29.88 \\
\hline
\end{tabular}

*Means followed by the same lowercase letter in the column do not differ statistically by the Tukey test ( $p<0.05$ ). MSD: minimum significant difference. 
For white spot in the assay of 2018 the treatments calcium, copper, manganese, zinc and water were all equal, differing only from the fungicide, that presented lower values of severity (Table 7). According to the fungicide leaflet used and works available in the literature, its active ingredients are able to control white spot, which justifies the lower values of severity.

Table 7: Area under white spot progress curve in corn, hybrids 30A37PW and FÓRMULA VIPTERA, treated with chelates-based products of calcium, copper, manganese and zinc. Novo Sarandi, Toledo - PR, second season, 2018.

\begin{tabular}{cc}
\hline Treatments & White spot \\
\hline Calcium & $46.76 a$ \\
Copper & $41.83 a$ \\
Manganese & $47.42 a$ \\
Zinc & $47.31 a$ \\
Fungicide & $24.35 \mathrm{~b}$ \\
Water & $48.40 \mathrm{a}$ \\
MSD & 9.29 \\
\hline
\end{tabular}

* Means followed by the same lowercase letter in the column do not differ statistically by the Tukey test ( $p<0.05$ ). MSD: minimum significant difference.

In the assay of 2018, as verified in 2017, the severity of gray leaf spot was higher for the hybrid FÓRMULA VIPTERA (Table 8), probably due to the characteristics of each hybrid, for example, the susceptibility of the hybrid FÓRMULA VIPTERA (Cruz et al., 2015), and moderate resistance of the hybrid 30A37PW (Pereira Filho; Borghi, 2016) for the pathogen C. zeae maydis. For the hybrid $30 \mathrm{~A} 37 \mathrm{PW}$ the fungicide differed from the water, while the chelates did not differ from water or fungicide. To the hybrid FÓRMULA VIPTERA, only the fungicide differed from the other treatments.

Jardine and Laca-Buendía (2009) observed a decrease in the severity of white spot and gray leaf spot in corn using azoxystrobin + cyproconazole in pre- $\mathrm{V}_{\mathrm{T}}$ as well as Vilela et al. (2012), applying pyraclostrobin + epoxiconazole and azoxystrobin + cyproconazole, also observed lower severity and incidence of these diseases.

Several studies demonstrate that adequate nutrition make plants less susceptible to the incidence of pathogens (Marschner, 2012), while excess and deficiency of certain nutrients may be responsible for the predisposition of plants to pathogens, both by altering the composition and growth of the plant, and by influencing the direct microbial activity on the leaves and soil (Bedendo; Amorim; Mattos-Jr, 2018).
Table 8: Area under gray leaf spot progress curve in maize, hybrids 30A37PW and FÓRMULA VIPTERA, treated with chelates-based products of calcium, copper, manganese and zinc. Novo Sarandi, Toledo - PR, second season, 2018.

\begin{tabular}{ccc}
\hline Treatments & 30A37PW & FÓRMULA VIPTERA \\
\hline Calcium & 167.63Bab & 642.17Aa \\
Copper & 160.45Bab & $633.77 \mathrm{Aa}$ \\
Manganese & $165.08 \mathrm{Bab}$ & $640.42 \mathrm{Aa}$ \\
Zinc & $169.25 \mathrm{Bab}$ & $645.67 \mathrm{Aa}$ \\
Fungicide & $102.33 \mathrm{Bb}$ & $431.92 \mathrm{Ab}$ \\
Water & $193.90 \mathrm{Ba}$ & $661.90 \mathrm{Aa}$ \\
MSD & 49.34 & 73.25 \\
\hline
\end{tabular}

*Means followed by the same lowercase letter in the column do not differ statistically by the Tukey test $(p<0.05)$. MSD: minimum significant difference.

Zambolim and Ventura (2012) also mention that nutrients can affect the mechanisms of resistance of plants, acting both in the formation of mechanical barriers, for example, the thickness of the cell wall, and in the synthesis of defense compounds, like phytoalexins, antioxidants and secondary metabolites. Nutrients can act on plant growth, which interferes with diseases, because the development of plants can affect the microclimate in the crop and, consequently, the infection and sporulation of the pathogen.

In this work the chelates showed no efficiency on the disease control, but it is important to mention that chemical correction of the soil was performed and the levels of both calcium, copper, manganese and zinc were adequate (Pauletti; Motta, 2019), therefore, there is no need to apply these nutrients via foliar. In cases of deficiency of some of these nutrients it is possible that more expressive and promising results could be achieved.

Zambolim and Ventura (2012) also affirm that plants that undergo stress of lack of nutrients are more susceptible than adequately nourished plants, which become tolerant or resistant to diseases. These authors also state that the impact of nutrients on plant diseases may vary, thus the same nutrient decreases the incidence of a disease and increases the incidence of another. So, considering these results, new studies in greenhouse, with inoculation of only one specific pathogen, could contribute to more expressive results, since in this study several diseases occurred simultaneously.

The various interactions that occur between the nutrients in a given system vary greatly, and influence the interaction among them, as absorption, availability 
and efficiency (Borges; Pinho; Pereira, 2009; Von Pinho et al., 2009; Setiyono et al., 2010). Thus, the different systems should be studied in order to understand these interactions and to find the balance among the nutrients, since according to Gott et al. (2014) the whole system must be balanced to achieve satisfactory results.

\section{CONCLUSIONS}

Calcium, copper, manganese and zinc-based chelate products were not able to influence the agronomic traits of second-crop corn or decrease the severity of the diseases evaluated in the edafoclimatic conditions in which the experiments were performed.

\section{REFERENCES}

AGROCERES. Guia agroceres de sanidade. São Paulo: Agroceres. 1994. 56p.

BEDENDO, I. P.; AMORIM, L.; MATTOS-JR, D. Ambiente e doença. In: AMORIN, L.; REZENDE, J. A. M.; BERGAMIN FILHO, A. Manual de fitopatologia: Princípios de conceitos. 5. Ed. Ouro Fino: Ceres, 2018. v.1, p.93-103.

BORGES, I. D.; PINHO, R. G.; VON; PEREIRA, J. L. A. R. Acúmulo de micronutrientes em híbridos de milho em diferentes estádios de desenvolvimento. Ciência e Agrotecnologia, 33(4):1018-1025, 2009.

BRASIL. Ministério da Agricultura, Pecuária e Abastecimento. Regras para análises de sementes. Ministério da Agricultura, Pecuária e Abastecimento. Secretaria de Defesa Agropecuária. Brasília, DF: Mapa/ ACS, 2009. 395p.

BRITO, C. H. et al. Redução de área foliar em milho em região tropical no Brasil e os efeitos em caracteres agronômicos. Interciencia, 36(4):291-295, 2011.

CARVALHO, R. V. et al. Manual de fitopatologia: Doenças das plantas cultivadas. 5. ed. Ouro Fino: Ceres, 2016. v.2, p.549-560.

CRUZ, C. D. Genes Software - Extended and integrated with the R, Matlab and Selegen. Acta Scientiarum. Agronomy, 38(4):547-552, 2016.

$C R U Z$, J. C. et al. Quatrocentas e setenta e sete cultivares de milho estão disponíveis no mercado de sementes do Brasil para a Safra 2015/16. Documentos 184. Sete Lagoas: Embrapa Milho e Sorgo, 2015. 28p. 1 edição.

CUNHA, J. P. A. R. et al. Aplicação aérea e terrestre de fungicida para o controle de doenças do milho. Revista Ciência Agronômica, 41(3):366-372, 2010.
DUARTE, R. P.; JULIATTI, F. C.; FREITAS, P. T. Eficácia de diferentes fungicidas na cultura do milho. Bioscience Journal, 25(4):101-111, 2009.

FAHAD, S.; BANO, A. Efeito do ácido salicílico na caracterização fisiológica e bioquímica do milho cultivado na área salina. Pakistan Journal of Botany, 44(4):1433-1438, 2012.

GOTT, R. M. et al. Índices diagnósticos para interpretação de análise foliar do milho. Revista Brasileira de Engenharia Agrícola e Ambiental, 18(11):1110-1115, 2014.

JARDINE, D. F.; LACA-BUENDIA, J. P. Eficiência de fungicidas no controle de doenças foliares na cultura do milho. FAZU em Revista, (6):11-52, 2009.

MANFROI, E. et al. Controle químico de doenças foliares e rendimento de grãos na cultura do milho. Revista Brasileira de Milho e Sorgo, 15(2):357-365, 2016.

MARSCHNER, $H$. Mineral nutrition of higher plants. New York: Academic Press, 3. ed. London: Elsevier, 2012. 643p.

MENDES, S. C. et al. Qualidade sanitária de grãos de milho com e sem inoculação a campo dos fungos causadores de podridões de espiga. Ciência e Agrotecnologia, 35(5):931939, 2011.

PAULETTI, V.; MOTTA, A. C. V. Calagem e adubação para as principais espécies de cereais cultivadas no estado do Paraná. In: PAULETTI, V.; MOTTA, A. C. V. Manual de adubação e calagem para o estado do Paraná. 1.ed. Curitiba: SBCS/NEPAR, 2017. cap. 8, p.161-200.

PEREIRA FILHO, I. A.; BORGHI, E. Mercado de sementes de milho no Brasil: Safra 2016/2017. 1.ed. Documentos 202. Sete lagoas: Embrapa Milho e Sorgo, 2016. 28p.

ROSA, W. B. et al. Desempenho agronômico de cinco híbridos de milho submetidos à aplicação de fungicida em diferentes estádios fenológicos. Revista Engenharia na Agricultura, 25(5):428-435, 2017.

SACHS, P. J. D. et al. Escala diagramática para avaliação da severidade da mancha branca em milho. Summa Phytopathologica, 37(4):202-204, 2011.

SANTOS, H. G. et al. Sistema brasileiro de classificação de solos. 3.ed. rev. e ampl., Rio de Janeiro: Embrapa Solos, 2013. 353p.

SETIYONO, T. D. et al. Estimating maize nutrient uptake requirements. Field Crops Research, 118(2):158-168, 2010.

SHANER, G.; FINNEY, R. E. The effect of nitrogen fertilization on the expression of slow-mildewing resistance in knox wheat. Phytopathology, 67(8):1051-1056, 1977. 
VILELA, R. G. et al. Desempenho agronômico de híbridos de milho em função da aplicação foliar de fungicidas. Bioscience Journal, 28(1):25-33, 2012.

VON PINHO, R. G. et al. Marcha de absorção de macronutrientes e acúmulo de matéria seca em milho. Revista Brasileira de Milho e Sorgo, 8(2):157-173. 2009.

WORDELL FILHO, J. Á.; CASA, R. T. Doenças na cultura do milho. In: WORDELL FILHO, J. A.; ELIAS, H. T. A cultura do milho em Santa Catarina. Florianópolis: Epagri. 2010. p.207-273.

ZAMBOLIM, L.; VENTURA, J. A. Mecanismos gerais dos nutrientes sobre a severidade de doenças de plantas. In: ZAMBOLIM, L.; VENTURA, J. A.; ZENÃO JÚNIOR, L. A. Efeito da nutrição mineral no controle de doenças de plantas. Viçosa: Universidade Federal de Viçosa Departamento de fitopatologia, v.1, 2012. p.25-45. 